\title{
Hastane Enfeksiyonu Etkeni Olan Metisiline Dirençli Staphylococcus aureus Suşlarında qacA/B Dezenfektan Direnç Genlerinin Varlığı ve Dezenfektanlara İn Vitro Duyarlılıklarının Araştırılması*
}

\author{
Investigation of the Presence of Disinfectant Resistance \\ Genes qacA/B in Nosocomial Methicillin-Resistant \\ Staphylococcus aureus Isolates and Evaluation of \\ Their In Vitro Disinfectant Susceptibilities
}

Şadiye Berna AYKAN ${ }^{1}$, Kayhan ÇAĞLAR ${ }^{1}$, Evren Doruk ENGIN ${ }^{2}$, Ayşe Bilge SIPAHI ${ }^{1}$, Nedim SULTAN ${ }^{1}$, Meltem YALINAY ÇIRAK ${ }^{1}$

${ }^{1}$ Gazi Üniversitesi Tıp Fakültesi, Tıbbi Mikrobiyoloji Anabilim Dalı, Ankara.

${ }^{1}$ Gazi University Faculty of Medicine, Department of Medical Microbiology, Ankara, Turkey.

${ }^{2}$ Ankara Üniversitesi Biyoteknoloji Enstitüsü, Ankara.

${ }^{2}$ Ankara University Biotechnology Institute, Ankara, Turkey.

* Bu çalışma, 6. Sterilizasyon ve Dezenfeksiyon Kongresi (1-5 Nisan 2009, Antalya)’nde poster olarak sunulmuştur.

Geliş Tarihi (Received): 10.04.2012 • Kabul Ediliş Tarihi (Accepted): 30.10 .2012

ÖZET

Hastane enfeksiyonlarına neden olan mikroorganizmalarda görülen dezenfektan direnci, dezenfektanların hastanelerde yaygın olarak kullanımı ya da önerilen konsantrasyonların altında kullanılmaları gibi yapılan yanlış uygulamalar sonucu gelişebilmektedir. Önemli bir hastane enfeksiyonu etkeni olan metisiline dirençli Staphylococcus aureus (MRSA), antibiyotiklere olduğu gibi dezenfektanlara karşı da dirençli olabilmekte; kuarterner amonyum bileşikleri ve diğer katyonik dezenfektanlara direnç oluşumundan sorumlu, plazmidlerle taşınan qacA/B genlerini bulundurabilmektedir. Bu çalısmada, hastane enfeksiyonu etkeni olan MRSA suşlarında qacA/B direnç genlerinin varlığının araştııılması; bu suşların dezenfektanlara karşı in vitro duyarlıı̆ı̆ının incelenmesi ve dezenfektan direnç geni bulunan suşlarda fenotipik direncin belirlenmesi amaçlanmıştır. Çalışmaya, klinik örneklerden izole edilen 69 nozokomiyal MRSA suşu dahil edilmiştir. Araştırmamızda, hastane enfeksiyonu etkeni olarak kabul edilen MRSA izolatlarının \%11.6 
Hastane Enfeksiyonu Etkeni Olan Metisiline Dirençli

Staphylococcus aureus Suşlarında qacA/B Dezenfektan Direnç Genlerinin

Varlığı ve Dezenfektanlara In Vitro Duyarlılıklarının Araştırıması

(8/69)'sında polimeraz zincir reaksiyonu (PCR) ile qacA/B dezenfektan direnç genlerinin varlığı saptanmıştır. Bu genlerin varlığının, fenotipik olarak da dezenfektan direncine yol açıp açmadığı, klorhekzidin ve benzalkonyum klorür gibi dezenfektanlarla bakteriyostatik ve bakterisidal testler yapılarak araştırılmıştır. Bu amaçla, CLSI önerileri doğrultusunda mikrodilüsyon yöntemi ile dezenfektanların minimal inhibitör konsantrasyon (MIK) değerleri belirlenmiş ve ayrıca BS EN 13727:2003 Avrupa standardı doğrultusunda kantitatif süspansiyon testi ile dezenfektanların bakterisidal etkileri araştırılmıştır. İzolatlardaki benzalkonyum klorür ve klorhekzidin MiK değerleri 2-8 $\mu \mathrm{g} / \mathrm{ml}$ arasında bulunmuştur. qacA/B geni pozitif bulunan izolatların beş tanesinde Mik değerlerinin daha yüksek olduğu ( $\geq 4 \mu \mathrm{g} / \mathrm{ml}$ ) görülmekle beraber, qacA/B geni pozitif $(n=8)$ ve negatif $(n=61)$ saptanan gruplar arasında istatistiksel olarak anlamlı bir fark izlenmemiştir. Kantitatif süspansiyon testinde, klorhekzidin ve benzalkonyum klorürün her ikisinin de \%1'lik klinik kullanım konsantrasyonu, qacA/B direnç geni bulunan ve bulunmayan tüm izolatlara bakterisidal etkili bulunmuştur. Sonuç olarak, qacA/B direnç geni taşıyan MRSA izolatlarında, dezenfektanların klinik kullanım konsantrasyonlarında direnç saptanmamış; yüksek Mik değerine sahip olan izolatlar için de bu dezenfektanlar bakterisidal etkili bulunmuştur. Dolayısıyla, direnç genlerinin varlığının ve dezenfektanlara karşı artmış Mík değerlerinin klinik anlamda direnç fenotipine yansımadıkları sonucuna varılmıştır.

Anahtar sözcükler: Metisiline dirençli Staphylococcus aureus; qacA/B geni; dezenfektan direnci; minimal inhibitör konsantrasyon; kantitatif süspansiyon testi.

\section{ABSTRACT}

Development of resistance to disinfectant substances in nosocomial microorganisms is an important problem encountered during disinfectant practices. Methicillin-resistant Staphylococcus aureus (MRSA) remains a significant cause of hospital-acquired infections. Besides being resistant to several antimicrobial agents, MRSA strains can also become resistant to some disinfectant substances. Resistance to disinfectant substances may develop due to the misuse of disinfectants. This may either be due to the frequent use of disinfectant substances or use in lower concentrations than recommended. MRSA strains may harbour the qacA/B disinfectant resistance genes that may cause resistance to quarternary ammonium compounds and some cationic disinfectants. These resistance genes are found in plasmids and are responsible for decreased susceptibility or resistance. In this study, a total of 69 nosocomial MRSA strains isolated from clinical specimens in our hospital were tested for disinfectant activity and the presence of qacA/B disinfectant resistance genes in these isolates was investigated by polymerase chain reaction. We determined whether the presence of these genes caused phenotypic resistance to chlorhexidine and benzalkonium chloride by the use of bactericidal and bacteriostatic tests. For this purpose, the minimum inhibitory concentration (MIC) values of these disinfectants against MRSA isolates were detected by microdilution method with the proposals of CLSI, and bactericidal effects of these disinfectants were also detected by using quantitative suspension test according to EN13727:2003 European Standard. It has been found that $11.6 \%(8 / 69)$ of the isolates harbored $q a c A / B$ resistance genes. MIC values for chlorhexidine and benzalkonium chloride were found in the range of $2-8 \mu \mathrm{g} / \mathrm{ml}$. Although it was observed that MIC values were higher in five of the qacA/B gene positive isolates, statistically significant difference was not found between gene positive and gene negative groups. Both $1 \%$ chlorhexidine and $1 \%$ benzalkonium chloride were found bactericidal against the isolates including the ones carrying the qacA/B resistance genes. It was concluded that the presence of the qacA/B disinfectant resistance genes did not lead to resistance to the disinfectant substances at the concentrations used in clinical practices. Furthermore, tested disinfectants still exhibited bactericidal activity even with high MIC values.

Key words: Methicillin-resistant Staphylococcus aureus; qacA/B gene; disinfectant resistance; minimum inhibitory concentration; quantitative suspension test. 


\section{Gíriş}

Hastane enfeksiyonlarının önlenmesinde ve kontrolünde uygun dezenfektanlardan yararlanılmaktadır. Hastane enfeksiyonu etkeni olan mikroorganizmalarda görülen dezenfektan direnci, dezenfeksiyon uygulamalarında karşılaşılan sorunlardan biridir. Bakterilerde 1950-1960'lı yıllarda gösterilmiş olan dezenfektan direncinin giderek arttığı bilinmektedir ${ }^{1}$. Dezenfektanlara karşı direnç, antibiyotik direncinde olduğu gibi doğal (kromozomal) ve kazanılmış (kromozomlardaki mutasyon, plazmid veya transpozon aracılı) direnç olarak karşımıza çıkmaktadır ${ }^{2,3}$.

Klinik örneklerden sıklıkla izole edilen ve birçok antibiyotiğe yüksek direnç oranları nedeniyle ciddi hastane enfeksiyonlarına yol açabilen Staphylococcus aureus suşlarında, kuarterner amonyum bileşiklerine direnç oluşumundan sorumlu genler tanımlanmış ve qac (quaternary ammonium compounds) olarak adlandırımıştır. Bu genler plazmidler üzerinde taşınmaktadır ve çok sayıda biyoside karşı azalmış duyarlıık veya dirençten sorumludur ${ }^{4}$. Günümüzde qac genlerinin qacA, qacB, qacC, qacD, qacG, qacH ve qacJ olmak üzere farklı tipleri tanımlanmıştır. Bunlar düşük düzeyde katyonik biyosid ve ilişkili antibiyotik direncinden sorumludur ${ }^{1,5}$. Metisiline dirençli S.aureus (MRSA) suşlarında \%5-72 arasında değişen oranlarda bulunan qacA/B geni, yüksek düzeyde dezenfektan ve antiseptik direnci ile ilişkilidir ${ }^{6,7}$. qacA/B direnç genleri plazmidler üzerinde taşındığı için, bu genlerin bulunması aynı zamanda antibiyotik direnci ile de ilişkili olabilmektedir. qacA/B genleri antiseptik direncine yol açmalarının dışında, aynı zamanda kimyasal olarak birbiriyle ilişkisiz birçok kimyasal maddeye de çapraz direnç oluşturabilir. Bu sebeple MRSA suşlarının direnç geni taşıyıp taşımadığının ve sahip olunan dezenfektan direnç genlerinin fenotipik yansımasının olup olmadığının belirlenmesi, MRSA kaynaklı hastane enfeksiyonlarının önlenmesi açısından önem taşımaktadır. Bu amaçla çalışmamızda, hastane enfeksiyonu etkeni olan MRSA suşlarında dezenfektan direnç genlerinin varlığı araştırılmış; bakterisidal ve bakteriyostatik testlerle MRSA suşlarının klorhekzidin ve benzalkonyum klorüre karşı in vitro duyarlılığı incelenmiş; qacA/B dezenfektan direnç geni bulunan suşlarda bu dezenfektanlara karşı fenotipik direncin olup olmadığı belirlenmiştir.

\section{GEREÇ ve YÖNTEM}

\section{Bakteri İzolasyonu}

Çalışmaya, Mayıs 2005-Haziran 2006 tarihleri arasında hastanemiz klinik mikrobiyoloji laboratuvarına gönderilen klinik örneklerden izole edilen ve hastane enfeksiyonu etkeni olduğu belirlenen 69 MRSA izolatı dahil edildi. Çalışmada her hastaya ait tek bir izolat kullanıldı. Çalışma öncesi tüm izolatların S.aureus oldukları konvansiyonel yöntemler ve otomatize tanımlama sistemi (API Staph; bioMerieux, Fransa) ile, MRSA olarak tanımlanmış izolatların metisilin direnci ise oksasilin disk difüzyon testi ile doğrulandı. Suşlar, saf kültürlerinden saklama şişelerine (Microbank, Pro-lab, Kanada) alındı ve moleküler, bakteriyostatik ve bakterisidal çalışmalara kadar $-30^{\circ} \mathrm{C}$ 'de saklandı.

\section{qacA/B Dezenfektan Direnç Genlerinin Saptanması}

Bakterilerden DNA izolasyonu yapılmadan önce, dondurularak saklanmış olan bakteri suşları Mueller Hinton besiyerine (Biolab, Macaristan) pasajlandı ve $37^{\circ} \mathrm{C}^{\prime}$ de 24 saat in- 
kübe edilerek canlandırıldı. $1 \mathrm{ml}$ TE (1X TrisEDTA) içerisinde bakteri süspansiyonları hazırlandıktan sonra 6500 rpm'de 5 dakika santrifüj edildi ve üst sıvı atıldı. Bu işlem her bir bakteri için üç kez olmak üzere tekrarlandı. $200 \mu \mathrm{l}$ TE içerisinde bakteri süspansiyonları hazırlandı ve $98^{\circ} \mathrm{C}^{\prime}$ de 20 dakika inkübe edildi. İnkübasyon sonrasında $14.000 \mathrm{rpm}$ 'de 10 dakika santrifüj edilerek hücresel atıklar çöktürüldü. DNA'nın bulunduğu üst sıvı temiz tüplere aktarılarak bakterilerden DNA izolasyonu tamamlandı.

Elde edilen DNA'larda qacA/B genlerinin varlığı, qacAB-forward (5'-TGGCTTTACCGGAATTAGTAAGAG-3') ve qaAAB-reverse (5'-GTCTTACGTCTAACATTGGAT CAG-3') primerleri kullanılarak polimeraz zincir reaksiyonu (PCR) ile araştırıldı. Primerlerin seçiminde National Centre for Biotechnology Information kor nükleotid veritabanında yer alan X56628 erişim numaralı qacA genini içeren kayıt ile AF053772 erişim numaralı qacB genini içeren kayıtlardan yararlanıldı. İki dizi ClustalW programı yardımıyla global olarak hizalandı. Dizilerin konsensus bölgeleri primer tasarımı için hedef bölge olarak seçildi. Bu bölge, PerlPrimer v1.1.21 programı ile analiz edildi ve 689 baz çifti (bç) uzunluğunda ürün çoğaltacak optimal primer çifti seçildi. PCR işlemi sırasında pozitif kontrol olarak Dr. N. Naguchi (Tokyo Üniversitesi, Japonya) ve Dr. N. Kobayashi (Sapporo Üniversitesi, Japonya) tarafından sağlanan toplam dört adet qacA/B geni pozitif MRSA izolatı, negatif kontrol olarak ise ön deneylerde qacA/B negatif bulunan MRSA suşları ve distile su kullanıldı.

Çalışmaya alınan suşlarda qacA ve qacB genlerinin taranması için $25 \mu l^{\prime}$ lik tepkime hacminde $50 \mathrm{mM}$ potasyum klorür, $10 \mathrm{mM}$ Tris hidroklorür, \%0.01 Tween-20, $3 \mathrm{mM}$ magnezyum klorür, her bir deoksinükleotid trifosfattan $0.2 \mathrm{mM}$, ileri ve geri primerlerden $0.2 \mu \mathrm{M}$, yaklaşık $100 \mathrm{ng}$ kalıp DNA eklendi. Termal döngü programı; $94^{\circ} \mathrm{C}^{\prime}$ de 2 dakika denatürasyonun ardından 40 döngü boyunca $94^{\circ} \mathrm{C}^{\prime}$ de 15 saniye denatürasyon, $56^{\circ} \mathrm{C}^{\prime}$ de 1 dakika birleşme ve $72^{\circ} \mathrm{C}^{\prime}$ de 1 dakika uzama olarak gerçekleştirildi. Son uzama için tüpler $72^{\circ} \mathrm{C}^{\prime}$ de 5 dakika inkübe edildi. Elde edilen amplifikasyon ürünleri, \%2'lik agaroz jel kullanılarak $5 \mathrm{~V} / \mathrm{cm}$ voltajda 60 dakika yürütüldü ve etidyum bromür ile boyandıktan sonra $254 \mathrm{~nm}$ dalga boyunda ışık kaynağına sahip transillüminatörde görüntülendi. Moleküler ağırlık standardı olarak, karışım haline getirilmiş 100-900, 1200 ve 1500 bç PCR ürünleri kullanıldı (SeeGene Forever Size Marker, ABD); 689 bç uzunlukta ürün çoğaltılan tüpler qacA ve/veya qacB pozitif olarak değerlendirildi.

\section{Bakteriyostatik Etkinin Belirlenmesi}

Klorhekzidin (Sigma, Almanya) ve benzalkonyum klorürün (Sigma, Almanya) MRSA izolatları için minimal inhibitör konsantrasyon (MiK) değerleri, CLSI önerileri doğrultusunda mikrodilüsyon yöntemiyle saptandı․ Buna göre mikroplaklarda dezenfektan konsantrasyonu $128 \mu \mathrm{g} / \mathrm{ml}$ ile $0.125 \mu \mathrm{g} / \mathrm{ml}$ arasında olacak şekilde sulandırımlar yapıldı ve test edilecek suşlar, her bir kuyucuğa $5 \times 10^{5}$ koloni oluşturan birim (kob) olacak şekilde inoküle edildi. Mikroplaklar $37^{\circ} \mathrm{C}^{\prime}$ de $24-48$ saat inkübe edildi ve değerlendirmede bulanıklığın olmadığı son kuyucuk her bakteri için Mik değeri olarak belirlendi. Mikrodilüsyon testleri her iki dezenfektan için tüm suşlarda iki kez tekrarlandı. 


\section{Kantitatif Süspansiyon Testi}

Dezenfektanların MRSA izolatlarına bakterisidal etkisinin incelenmesinde kantitatif süspansiyon testi Avrupa standardı EN13727:2003 testi kullanıldı9. Bu amaçla, benzalkonyum klorür (Zefiran forte; 100 cc'de $10 \mathrm{~g}$ benzalkonyum klorür, İlsan, Türkiye) ve klorhekzidinin (Savlex; \%15 setrimid, \%1.5 klorheksidin glukonat, Drogsan, Türkiye) klinik kullanımda önerilen \%1'lik konsantrasyonlarındaki bakterisidal etkisi tüm suşlar için belirlendi. Standart suşlar olarak Pseudomonas aeruginosa ATCC 15442, S.aureus ATCC 6538 ve Enterococcus hirae ATCC 10541 kullanıldı. Nötralizan olarak her iki dezenfektan için lesitin 30 g/L (Nattermann, Almanya), Tween 8030 g/L (Merck, Almanya) ve Saponin $30 \mathrm{~g} / \mathrm{L}$ (Fluka, İsviçre) kullanıldı. Kontrol deneylerinde, dezenfektan dışındaki test koşullarının letal etkisinin olmadığı, kullanılan nötralizanın toksik etkisinin bulunmadığı ve dezenfektanı nötralize ettiği gösterildi. Bu amaçla, kontrol bakterileri kullanılarak hazırlanan test süspansiyonu, $10^{-3}$ ile $10^{-5}$ oranında seyreltilerek validasyon süspansiyonu hazırlandı. İlk aşamada $1 \mathrm{ml}$ kirletici madde $+1 \mathrm{ml}$ validasyon süspansiyonu $+8 \mathrm{ml}$ sert su kullanılarak sert su ve kirletici maddenin mikroorganizma sayısını azaltmadığı, yani letal etkisi olmadığı gösterildi. İkinci aşamada nötralizan, validasyon süspansiyonu ile bekletildi ve nötralizanın letal olmadığı gösterildi. Üçüncü aşamada ise $1 \mathrm{ml}$ kirletici madde $+1 \mu \mathrm{l}$ dilüent $+8 \mathrm{ml}$ dezenfektan bir tüpte karıştıııldı. Buradan $1 \mathrm{ml}$ alınarak $8 \mathrm{ml}$ nötralizan ile muamele edildi; 5 dakika sonra üzerine $1 \mathrm{ml}$ validasyon süspansiyonu eklendi ve bir süre sonra triptik soy agar (TSA) besiyerine ekim yapıldı. Böylece nötralizanın dezenfektanı nötralize ettiği gösterildi. Kantitafif süspansiyon testinde, bakterilerin test süspansiyonu $1.5 \times 10^{8}-5 \times 10^{8} \mathrm{kob} / \mathrm{ml}$ olarak hazırlandı ve deneyler kirletici madde varlığında $(3 \mathrm{~g} / \mathrm{L}$ sığır albumini ve $3 \mathrm{ml} / \mathrm{L}$ yıkanmış eritrosit süspansiyonu) gerçekleştirildi. Bakteri solüsyonu ile dezenfektan bir tüp içinde 1 ve 5 dakika bekletildikten sonra, buradan bir miktar alınarak başka bir tüp içindeki nötralizan solüsyon içine aktarıldı ve ardından da TSA plaklarına ekimleri yapıldı. Dezenfektanların bakterisidal etkileri, 24 saat inkübasyon sonrasında TSA besiyerinde canlı kalan bakteri sayısı belirlenerek değerlendirildi. Başlangıçtaki koIoni sayısıyla karşılaştırıldığında, inkübasyon sonundaki koloni sayısındaki 5 logaritmalık azalma bakterisidal etki olarak kabul edildi. Tüm deneyler ikişer kez tekrarlandı.

\section{İstatistiksel Analiz}

qacA/B direnç geni bulunan ve bulunmayan izolatların Mík değerleri arasındaki farkın önemi Mann-Whitney U testi ile belirlendi.

\section{BULGULAR}

Çalışmamızda, hastane enfeksiyonu etkeni olan 69 MRSA suşunun 8 (\%11.6)'inde qaCA/B dezenfektan direnç geni saptanmıştır (Resim 1). Bu sekiz suşun üçünde benzalkonyum klorür ve klorhekzidin MiK değerleri, her iki dezenfektan için de benzer olarak 2 $\mu \mathrm{g} / \mathrm{ml}$, dördünde $4 \mu \mathrm{g} / \mathrm{ml}$ ve birinde $8 \mu \mathrm{g} / \mathrm{ml}$ olarak bulunmuştur (Tablo I). MRSA suşlarında qacA/B gen varlığına göre benzalkonyum klorür ve klorheksidin Mí değerlerinin dağılımı Tablo I'de gösterilmiştir. Sonuçlar incelendiğinde, qacA/B geni pozitif bulunan izolatların beşinde her iki dezenfektana ait MiK değerlerinin daha yüksek olduğu görül- 
Hastane Enfeksiyonu Etkeni Olan Metisiline Dirençli

Staphylococcus aureus Suşlarında qacA/B Dezenfektan Direnç Genlerinin

Varlığı ve Dezenfektanlara In Vitro Duyarlıııkarının Araştırılması

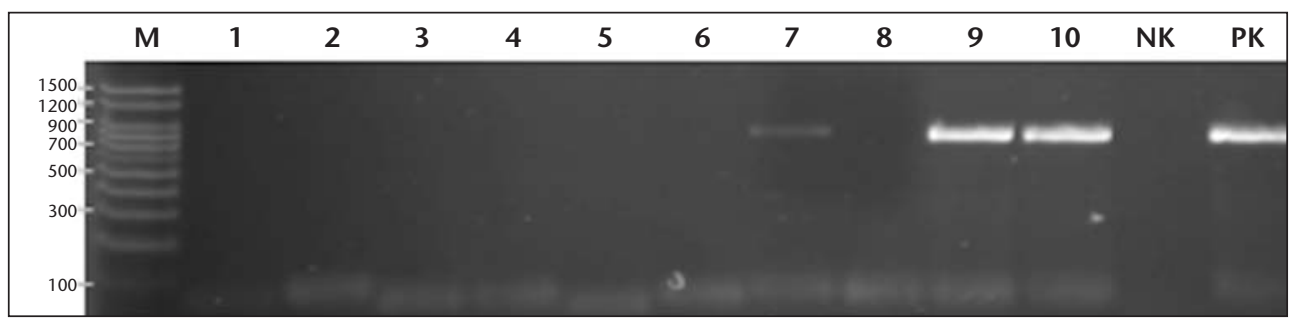

Resim 1. $P C R$ sonucu qacAB-f/r primer çifti ile elde edilen amplikonların görüntüsü (M: DNA moleküler ağırlık standardı; Hat 9 ve 10: qacAB geni pozitif suşlar; NK: Negatif kontrol; PK: Pozitif kontrol).

Tablo I. MRSA Suşlarında qacA/B Gen Varlı̆̆ına Göre Benzalkonyum Klorür ve Klorhekzidin lçin Mik Değerlerinin Dağılımı

\begin{tabular}{|c|c|c|c|c|c|c|}
\hline \multirow[b]{2}{*}{$\begin{array}{l}\text { Mik değeri } \\
(\mu \mathrm{g} / \mathrm{ml})\end{array}$} & \multicolumn{3}{|c|}{$\begin{array}{c}\text { Benzalkonyum klorür } \\
\text { Sayı (\%) }\end{array}$} & \multicolumn{3}{|c|}{$\begin{array}{l}\text { Klorhekzidin } \\
\text { Sayı (\%) }\end{array}$} \\
\hline & $\begin{array}{l}\text { qacA/B } \\
\text { negatif }\end{array}$ & $\begin{array}{l}\text { qacA/B } \\
\text { pozitif }\end{array}$ & Toplam & $\begin{array}{l}\text { qacA/B } \\
\text { negatif }\end{array}$ & $\begin{array}{l}\text { qacA/B } \\
\text { pozitif }\end{array}$ & Toplam \\
\hline 2 & $32(52.5)$ & $3(37.5)$ & $35(50.7)$ & $38(62.3)$ & $3(37.5)$ & $41(59.4)$ \\
\hline 4 & $23(37.7)$ & $4(50)$ & $27(39.1)$ & $21(34.4)$ & $4(50)$ & $25(36.2)$ \\
\hline 8 & $6(9.8)$ & $1(12.5)$ & $7(10.2)$ & $2(3.3)$ & $1(12.5)$ & $3(4.4)$ \\
\hline Toplam & $61(100)$ & $8(100)$ & $69(100)$ & $61(100)$ & $8(100)$ & $69(100)$ \\
\hline
\end{tabular}

MRSA: Metisiline dirençli S.aureus; MiK: Minimal inhibitör konsantrasyon.

mekle beraber, qacA/B geni pozitif ve negatif gruplar arasında istatistiksel olarak anlamIı bir fark saptanmamıştır.

Bakterisidal etkinin incelendiği kantitatif süspansiyon testi sonuçlarına göre, her iki dezenfektanın klinik kullanımda önerilen \%1'lik konsantrasyonları, qacA/B geni pozitifliği saptanan MRSA suşları da dahil olmak üzere çalışılan tüm izolatlarda bakterisidal etkili bulunmuştur. Buna göre, çalışmada kullanılan dezenfektanların, yüksek MíK değerlerine ( $\geq 4 \mu \mathrm{g} / \mathrm{ml}$ ) sahip izolatlara da öldürücü etki gösterdiği izlenmiştir.

\section{TARTIŞMA}

Hastane enfeksiyonu etkeni MRSA'lar, farklı antibiyotiklere dirençli olduğu gibi dezenfektanlara da dirençli olabilmektedir. Dirençli stafilokokların ve diğer dirençli bakterilerin hastanelerde yaygın olarak bulunmasının bir sebebinin antibiyotik kullanımına ek olarak dezenfektan ve antiseptiklerin hastane ortamlarında sık kullanımına bağlı olduğu ileri sürülmektedir ${ }^{10}$. Hastanelerde dezenfektanların gereksiz, fazla veya önerilen konsantrasyonun altında kullanılması ya da bakterilerin dezenfektanın rezidüel konsantrasyonlarına maruz kalması bu maddelere direnç gelişmesine yol açabilmektedir ${ }^{11,12}$. Kuarterner amonyum bileşikleri gibi katyonik dezenfektanların yaygın kullanımının çoklu ilaç dışa atım pompasına sahip olan ve qacA/B genlerini bulunduran bakterilerin seçimine neden olduğu düşünülmektedir ${ }^{1}$. Plazmidlerle taşınan qacA/B genleri, bazı katyonik dezenfektanlara ve biguanidlere (klorhekzidin) karşı direnç gelişimi ile ilişkilidir ${ }^{13}$. Klorhekzidin gi- 
bi katyonik dezenfektanların hastanelerde yaygın olarak kullanımının, qacA/B direnç genlerini taşıyan bakterilerin seçilmesine ve artışına yol açtığı da ileri sürülmektedir ${ }^{5}$.

Çalışmamızda, hastane enfeksiyonu etkeni olarak izole edilen MRSA suşlarının \%11.6'sında qacA/B genlerinin varlığı saptanmıştır. Bu genlerin prevalansı farklı ülkelerden yapılan çalışmalarda değişik oranlarda bildirilmiştir ${ }^{6,7,14-17}$. Mayer ve arkadaşları ${ }^{6}$, Avrupa'nın farklı şehirlerinden topladıkları 297 MRSA suşunun \%63'ünde, 200 metisiline duyarlı S.aureus (MSSA) suşunun ise \%12'sinde qacA/B varlığını bildirmişlerdir. Araştırıcılar, yüksek qacA/B gen prevalansının, enfeksiyon önleyici ajanların hastanelerde yaygın kullanımının zorunlu seçici etkisinden kaynaklandığını belirtmişler; qacA/B direnç genlerinin MRSA'larda daha yüksek oranda saptanmasını ise, bu genlerin çoklu ilaç direnci taşıyan plazmidlerde yaygın olarak bulunmasına bağlamışlardır ${ }^{6}$. Yapılan diğer çaIışmalarda da qac genleri pozitifliği, Tunus'ta ${ }^{17}$ S.aureus suşlarında $\% 12.8$; Japonya' da ${ }^{14}$ MRSA suşlarında \%10.2; Kanada'da ${ }^{18}$ MRSA suşlarında \%2 ve Asya ülkelerinde ${ }^{7}$ MRSA suşlarında \%41.6 (372/894) oranında bildirilmiştir. Asya ülkelerinde yapılan çalışmada, bu genlerin bulunma sıklığının \%5 (Çin) ile \%72 (Singapur) arasında olmak üzere oldukça değişkenlik gösterdiği izlenmiştir ${ }^{7}$. Ülkemizde ise bu konuda çok az veri bulunmakta olup, yapılan bir çalışmada, MRSA'larda qacA/B direnç genine rastlanmadığı, ancak MSSA izolatlarında \%2.2 oranında bulunduğu bildirilmiştir ${ }^{19}$. Bu konuda geniş ölçekli çalışmaların yapılması, qacA/B genlerinin ülkemizin farklı bölgelerindeki prevalansı hakkında daha sağlıklı bilgi edinilmesini sağlayacaktır.

Literatürde, hem direnç genlerinin varlığının hem de dezenfektanın klinik kullanımına karşı bir direnç bulunup bulunmadığının birlikte araştırıldığı az sayıda çalışma mevcuttur. Yapılan çalışmalarda genellikle direnç genleri ile birlikte dezenfektanların Mik değerlerine bakılmış, dezenfektanın letal etkileri ise araştııılmamıştır ${ }^{16,20-22}$. Bu konudaki bilgiler sınırlı olup genellikle sadece dezenfektanların MiK değerlerine bakılarak yorumlar yapılmaktadır. Ancak dezenfektana karşı yüksek Mík değeri saptanmış olsa bile, bakteri o dezenfektanın kullanım konsantrasyonuna karşı direnç göstermeyebilir. Zira dezenfektanın önerilen kullanım konsantrasyonu, pratikte MiK değerlerinin çok üzerindedir ve dolayısıyla dezenfektana karşı gerçek bir direnç olmayabilir. Smith ve arkadaşları ${ }^{23}$ benzalkonyum klorür ve klorhekzidinin MRSA izolatlarındaki minimal bakterisidal konsantrasyonunu (MBC) mikrodilüsyon yöntemiyle araştırmışlar; qac geni taşıyan izolatlardaki $M B C$ değerlerini taşımayanlara göre anlamlı düzeyde yüksek bulmuşlardır. Ancak bulunan MBC değerleri bu dezenfektanlar için önerilen klinik kullanım konsantrasyonunun çok altındadır ${ }^{23}$. Bir başka deyişle, eğer dezenfektanların kullanım konsantrasyonları doğru şekilde uygulanırsa bu bakterilerde bir direnç görülmeyecek ve izolatların hepsi ölecektir. Dolayısıyla, dezenfektanların klinik kullanım konsantrasyonlarında bakteriler üzerindeki öldürücü etkilerinin belirlenmesi önem taşımaktadır. Bu amaçla kullanılan yöntem ise kantitatif süspansiyon testidir ${ }^{24-26}$. Bu test bakterilerdeki dezenfektan direncini mikrodilüsyon testine göre çok daha doğru olarak belirler; zira kantitatif süspansiyon testinde dezenfektanlar klinik kullanımda olduğu gibi gerçek kullanım konsantrasyonlarında kullanılmaktadır. Bu yöntem ile, dezenfektanın bakteriye letal etki göstermediğinin saptanması, bakterilerde gerçek bir biyosid direncini ifade etmektedir. Bizim çalışmamız- 
da da, qacA/B direnç genlerinin prevalansının belirlenmesinin yanında, klorhekzidin ve benzalkonyum klorürün MRSA izolatlarına karşı MiK değerleri ve ayrıca kantitatif süspansiyon testi ile öldürücü etkileri araştııılmıştır. Böylece bakterilerde direnç genlerinin genotipik olarak bulunmasının yanı sıra fenotipik olarak da dezenfektanlara karşı bir direnç olup olmadığı irdelenmiştir.

Çalışmamızda, qacA/B geni saptanan izolatların çoğunda (5/8) her iki dezenfektanın MiK değerleri ( $>2 \mu \mathrm{g} / \mathrm{ml})$, bu geni taşımayan izolatlara göre, istatistiksel olarak anlamlı fark bulunmasa da, daha yüksek saptanmıştır. Literatürdeki klorhekzidin ve benzalkonyum klorür MiK değerlerinin araştırıldığı çalışmalar incelendiğinde, $2 \mu \mathrm{g} / \mathrm{ml}$ 'nin üzerindeki MiK değerlerinin genellikle yüksek olarak kabul edildiği, hatta bazı araştıııııların 2 $\mu \mathrm{g} / \mathrm{ml}$ 'nin üzerindeki değerlere sahip izolatları dirençli olarak bildirdikleri görülmekte$\operatorname{dir}^{2,17,27,28}$. Irizary ve arkadaşlarını ${ }^{27}$ çalışmasında klorhekzidin MiK değerleri MSSA'ların $\% 83^{\prime}$ ünde $\leq 2 \mu \mathrm{g} / \mathrm{ml}$; MRSA'ların ise $\% 83^{\prime}$ ünde $\geq 2 \mu \mathrm{g} / \mathrm{ml}$ olarak bulunmuş; araştırıcılar, yüksek MiK değerlerini göz önüne alarak MRSA'ların klorhekzidine karşı duyarlıı̆̆ının azaldığını belirtmişlerdir. Bir başka çalışmada, qacA geni taşıyan ve taşımayan S.aureus izolatlarında klorhekzidin MiK değerleri sırasılla 2 ve $0.8 \mu \mathrm{g} / \mathrm{ml}$; benzalkonyum klorür için sırasıyla $6 \mathrm{ve}<2 \mu \mathrm{g} / \mathrm{ml}$ olarak bildirilmiştir ${ }^{28}$. Noguchi ve arkadaşları ${ }^{14}$ qacA geni bulunan MRSA izolatlarında katyonik antiseptiklere karşı MiK değerlerini $(>2 \mu \mathrm{g} / \mathrm{ml})$, bu geni bulundurmayan izolatlara $(<2 \mu \mathrm{g} / \mathrm{ml})$ göre daha yüksek olarak saptamışlardır. Bizim çalışmamızda da, qacA/B direnç geni taşıyan ve taşımayan tüm MRSA izolatlarında Mík değerleri genel olarak yüksek ( $\geq 2 \mu \mathrm{g} / \mathrm{ml}$ ) bulunmuş; bu durumun, hastanemizde klorhekzidin ve benzalkonyum klorürün yaygın olarak kullanımından kaynaklandığı düşünülmüştür. Bununla birlikte, yüksek MiK değerlerinin saptanması, dezenfektanın daha az inhibitör etki gösterdiği ya da dezenfektana karşı bakterilerin dirençli olduğu anlamına gelmemektedir; zira dezenfektan çalışmalarında antibiyotiklerde olduğu gibi duyarııık ve dirençlilik sınırlarını gösteren kesin olarak belirlenmiş sınır değerleri yoktur. Bu nedenle, bakterilerin dezenfektanlara dirençli olarak bildirildiği birçok çalışmada, konunun bu yönü eksik kalmaktadır. Dolayısıyla, sadece yüksek MiK değerlerine bakılarak bakterilerin dirençli olduğunu ileri sürmek doğru bir yorum olmayabilir; çünkü bu çalısmalarda genellikle dezenfektanların klinik kullanım konsantrasyonlarında bakterilere karşı öldürücü etkilerine bakılmamış ve sadece yüksek MiK değerlerine göre yorum yapılmışır. Ancak, yalnızca yüksek MiK değerleri dikkate alınarak, bakterilerde gerçek bir dezenfek$\tan$ direncinin olduğunun ileri sürülmesi doğru değildir. Nitekim Cookson ve arkadaşla$\mathrm{rI}^{29}$, direnç geni bulunmasının klorhekzidinin öldürücü etkisinde bir değişiklik yapmadığını bildirmektedir. Bizim çalışmamızın sonuçları da bu yoruma paralellik göstermiş ve kantitatif süspansiyon testi ile yüksek MiK değerlerine sahip olan izolatların da diğer izolatlarda olduğu gibi, dezenfektanların klinik kullanım konsantrasyonuna (\%1) karşı duyarlı olduğu saptanmışır. Artmış MiK değerlerinin dezenfektanların klinik uygulamasında anlamının olmamasının sebepleri arasında, dezenfektanın bakteri hücresi üzerinde çok sayıda hedef bölgesinin bulunması ve dezenfektanın klinik kullanım konsantrasyonIarının MIK düzeylerinin kat kat üzerinde olması sayılabilir. Bunun sonucunda bakterinin artmış MiK değerlerine sahip olmasına veya direnç geni taşımasına rağmen, dezenfektan bakterisidal etki gösterebilmektedir. 
Sonuç olarak çalışmamızda, hastane enfeksiyonu etkeni olan MRSA suşlarında PCR yöntemi ile \%11.6 (8/69) oranında qacA/B geni pozitifliği saptanmış; klorhekzidin ve benzalkonyum klorür solüsyonunun \%1'lik konsantrasyonları gerek qacA/B geni taşıyan gerekse yüksek MiK ( $\geq 2 \mu \mathrm{g} / \mathrm{ml}$ ) değerlerine sahip MRSA suşlarının hepsi için bakterisidal etkili bulunmuş; buna göre direnç genlerinin varlığının ve artmış MíK değerlerinin direnç fenotipine yansımadığı sonucuna varılmıştır.

\section{KAYNAKLAR}

1. Russell AD. Introduction of biocides into clinical practice and the impact on antibiotic-resistant bacteria. J Appl Microbiol 2002; 92(Suppl): 121S-35S.

2. McDonnell G, Russell AD. Antiseptics and disinfectants: activity, action, and resistance. Clin Microbiol Rev 1999; 12(1): 147-79.

3. Poole K. Mechanisms of bacterial biocide and antibiotic resistance. J Appl Microbiol 2002; 92(Suppl): 55S$64 S$.

4. Fraise AP. Susceptibility of antibiotic-resistant cocci to biocides. J Appl Microbiol 2002; 92(Suppl): 158S625 .

5. Paulsen IT, Brown MH, Skurray RA. Characterization of the earliest known Staphylococcus aureus plasmid encoding a multidrug efflux system. J Bacteriol 1998; 180(13): 3477-9.

6. Mayer S, Boos M, Beyer A, Fluit AC, Schmitz FJ. Distribution of the antiseptic resistance genes qacA, qacB, and qacC in 497 methicillin-resistance and -susceptible European isolates of Staphylococcus aureus. J Antimicrob Chemother 2001; 47(6): 896-7.

7. Noguchi N, Suwa J, Narui K, et al. Susceptibilities to antiseptic agents and distribution of antiseptic-resistance genes qacA/B and smr of methicillin-resistant Staphylococcus aureus isolated in Asia during 19981999. J Med Microbiol 2005; 54(6): 557-65.

8. Clinical and Laboratory Standards Institute. Methods for dilution antimicrobial susceptibility tests for bacteria that grow aerobically. Approved Standard, $7^{\text {th }}$ edition, 2006, CLSI Document M7-A7. CLSI, Wayne, PA.

9. British Standards Institution. Chemical disinfectants and antiseptics. Quantitative suspension test for the evaluation of bactericidal activity of chemical disinfectants for instruments used in the medical area. Test method and requirements (Phase 2/Step 1). BS EN 13727: 2003. British-Adopted European Standard, UK.

10. Russell AD. Biocide use and antibiotic resistance: the relevance of laboratory findings to clinical and environmental situations. Lancet Infect Dis 2003; 3(12): 794-803.

11. Thomas L, Maillard JY, Lambert RJ, Russell AD. Development of resistance to chlorhexidine diacetate in Pseudomonas aeruginosa and the effect of a residual concentration. J Hosp Infect 2000; 46(4): 297-303.

12. Block C, Furman M. Association between intensity of chlorhexidine use and micro-organisms of reduced susceptibility in a hospital environment. J Hosp Infect 2005; 51(3): 201-6.

13. Putnam M, van Ween HW, Konings WN. Molecular properties of bacterial multidrug transporters. Microbiol Mol Biol Rev 2000; 64(4): 672-93.

14. Noguchi N, Hase M, Kitta M, Sasatsu M, Deguchi K, Kono M. Antiseptic susceptibility and distribution of antiseptic-resistance genes in methicillin-resistant Staphylococcus aureus. FEMS Microbiol Lett 1999; 172(2): 247-53.

15. Alam MM, Kobayashi N, Uehara N, Watanabe N. Analysis on distribution and genomic diversity of high-level antiseptic resistance genes qacA and qacB in human clinical isolates of Staphylococcus aureus. Microb Drug Resist 2003; 9(2): 109-21.

16. Noguchi N, Nakaminami H, Nishijima S, Kurokawa I, So H, Sasatsu M. Antimicrobial agent of susceptibilities and antiseptic resistance gene distribution among methicillin-resistant Staphylococcus aureus isolates from patients with impetigo and staphylococcal scalded skin syndrome. J Clin Microbiol 2006; 44(6): 2119-25. 
Hastane Enfeksiyonu Etkeni Olan Metisiline Dirençli

Staphylococcus aureus Suşlarında qacA/B Dezenfektan Direnç Genlerinin

Varlığı ve Dezenfektanlara In Vitro Duyarlııklarının Araştıııması

17. Zmantar T, Kouidhi B, Miladi H, Bakhrouf A. Detection of macrolide and disinfectant resistance genes in clinical Staphylococcus aureus and coagulase-negative staphylococci. BMC Res Notes 2011; 4: 453.

18. Longtin J, Seah C, Siebert K, et al. Distribution of antiseptic resistance genes qacA, qacB, and smr in methicillin-resistant Staphylococcus aureus isolated in Toronto, Canada, from 2005 to 2009. Antimicrob Agent Chemother 2011; 55(6): 2999-3001.

19. Nakipoğlu Y, Ignak S, Gurler N, Gurler B. The prevalence of antiseptic resistance genes (qacA/B and smr) and antibiotic resistance in clinical Staphylococcus aureus strains. Mikrobiyol Bul 2012; 46(2): 180-9.

20. Sheng WH, Wang JT, Lauderlale TL. Epidemiology and susceptibilities of methicillin-resistant Staphylococcus aureus in Taiwan: emphasis on chlorhexidine susceptibility. Diagn Microb Infect Dis 2009; 69 (3): 309-13.

21. Zhang M, O'Donoghue MM, Ito T, Hiramatsu K, Boost MV. Prevalence of antiseptic-resistance genes in Staphylococcus aureus and coagulase-negative staphylococci colonising nurses and the general population in Hong Kong. J Hosp Infect 2011; 78(2): 113-7.

22. Shamsudin MN, Alreshidi MA, Hamat RA, et al. High prevalence of qacA/B carriage among clinical isolates of methicillin-resistant Staphylococcus aureus in Malaysia. J Hosp Infect 2012; 81(3): 206-8.

23. Smith K, Gemmel CG, Hunter IS. The association between biocide tolerance and the presence or absence of qac genes among hospital-acquired and community-acquired MRSA isolates. J Antimicrob Chemother 2008; 61(1): 78-84.

24. Espirages E, Bueno A, Fernandez-Crehuet M, Espirages M. Efficacy of some neutralizers in suspension tests determining the activity of disinfectants. J Hosp Infect 2003; 55(2): 137-40.

25. Wisplinghoff A, Schmitt R, Wöhrmann A, Stefanik D, Seifert H. Resistance to disinfectants in epidemiologically defined clinical isolates of Acinetobacter baumannii. J Hosp Infect 2007; 66(2): 174-81.

26. Garcia-de-Lomas J, Lerma M, Cebrian L, et al. Evaluation of the in-vitro cidal activity and toxicity of a novel peroxygen biocide: 2-butanone peroxide. J Hosp Infect 2008; 68(3): 248-54.

27. Irizarry L, Merlin T, Rupp J, Griffith J. Reduced susceptibility of methicillin-resistant Staphylococcus aureus to cetylpyridinium chloride and chlorhexidine. Chemotherapy 1996; 42(4): 248-52.

28. Littlejohn TG, Paulsen IT, Gillespie MT, et al. Substrate specificity and energetics of antiseptic and disinfectant resistance in Staphylococcus aureus. FEMS Microbiol Lett 1992; 74(2-3): 259-65.

29. Cookson BD, Bolton MC, Platt JH. Chlorhexidine resistance in methicillin-resistant Staphylococcus aureus or just an elevated MIC? An in-vitro and in-vivo assessment. Antimicrob Agents Chemother 1991; 35(10): 1997-2002. 